\title{
On the Efficiency Objection to Workplace Democracy
}

\author{
JORDAN WALTERS \\ Philosophy, McGill University \\ jordan.walters@mail.mcgill.ca
}

\begin{abstract}
Are workers dominated? A recent suite of neo-republican and relational egalitarian philosophers think they are. Suppose they are right; that is, suppose that some workers are governed by an unjust and arbitrary power existing in labour relations, which persists even in the presence of the actual ability to exit. My question is this: does that give us reason to impose restrictions on firms? According to the so-called Efficiency Objection there are relevant trade-offs that need to be considered between the efficiency of firms and the freedom of workers, and upon considering these trade-offs, we should reject workplace democracy. In this paper, I present a dilemma for the Efficiency Objection. I argue that either the Efficiency Objection is justified on moral grounds or non-moral grounds; if the Efficiency Objection is justified on moral grounds, then it fails because efficiency cannot be valued for its own sake (it is only instrumentally good); if the Efficiency Objection is justified on nonmoral grounds, then it fails because of the respect that we owe to persons as persons; therefore, the Efficiency Objection fails.
\end{abstract}

\section{$\$ 1$ Introduction}

Are workers dominated? A recent suite of neo-republican (and relational egalitarian) philosophers think they are. ${ }^{1}$ One proposed remedy to this problem is to introduce some form of workplace democracy-i.e., the ability for workers to participate in the actual governance of their respective firms. ${ }^{2}$ As Elizabeth Anderson aptly puts it:

\footnotetext{
1 See Anderson (2015, 2017), Breen (2015), González-Ricoy (2014; 2020), Hirvonen \& Breen (2020), Hsieh (2005), Landes \& Néron (2018), Neron (2015), O’Shea (2019; 2020a), and Vrousalis (2021).

${ }^{2}$ For a recent survey of arguments for workplace democracy see Frega et al., (2019). See also Breen (2015; 2017) GonzálezRicoy (2014; 2020), Landemore \& Ferreras (2016), and Néron (2015) as cited in Hirvonen \& Breen (2020).

See also Hsieh $(2005 ; 2009)$ as cited in O’Neill (2017).
} 
[E]xit, rule of law constraints on employers, [and] constitutional rights [...] are not sufficient-workers need some voice within the workplace to protect against employer abuses of power, and, more generally, to empower them to assert their standing, respectability, and autonomy interests in the workplace (Anderson, 2017: 133).

Suppose that Anderson is right; that is, suppose that some workers are governed by an unjust and arbitrary power existing in labour relations, which persists even in the presence of the actual ability to exit. $^{3}$ My question is this: does that give us reason to impose restrictions on firms? According to the Efficiency Objection, there are relevant trade-offs that need to be considered between the efficiency of firms and the freedom of workers, and upon considering these trade-offs, we should reject workplace democracy. ${ }^{4}$ To get a rough sense of these trade-offs, consider what Tyler Cowen writes in response to Anderson's proposal:

Anderson mentions the German codetermination model, whereby workers sit on the boards of corporations. The best study I know indicates that this organizational form costs about 26 percent of shareholder value because of the lower productivity, and furthermore a lot of that burden is born by consumers, who are mostly workers in another guise (Anderson, 2017: 116).

If Cowen is right, then even if workers are dominated, it does not immediately follow that we have reason to impose restrictions on firms; we must first consider the trade-offs between efficient firms and the freedom of workers. In this paper, I argue that the Efficiency Objection fails.

\footnotetext{
${ }^{3}$ See Anderson (2017: 45).

${ }^{4}$ See Frega, Herzog, \& Neuhäuser (2019: §3.1) for an overview. See Frye (2020) and O’Shea (2020b) for a recent debate over the relationship between non-domination and efficiency. See $\$ 4$ for a more nuanced treatment of the Efficiency Objection.
} 
This essay has five sections. In $\$ 2$, I present the neo-republican (and relational egalitarian) case that workers are dominated. In $\$ 3, I$ present the Efficiency Objection to workplace democracy. In $\$ 4, I$ argue that the Efficiency Objection fails. In \5, I conclude.

\section{\$2 The Case for Workplace Democracy}

Let us start with a case:

SLAUGHTERHOUSE WORKER: David, a young immigrant man, works six days a week at a slaughterhouse in California to support his family. Temperatures in the slaughterhouse often reach a sweltering 100 degrees Fahrenheit, and due to a lack of adequate bathroom breaks, David and his co-workers are forced to either wear diapers or defecate on themselves. ${ }^{5}$ Moreover, despite the obvious exhaustion of David and his co-workers, 'team leaders' continue to pressure workers to ever-increasing productivity (for they too, have their bosses to serve). Given these working conditions, David sometimes contemplates filing a complaint, but his boss often threatens to fire workers who complain. Finally, David has no input on his fluctuating work schedule and is often too exhausted to do anything but recover on his days off. Hence, David routinely disregards the possibility of leaving the slaughterhouse and starting anew. ${ }^{6}$

According to the orthodox position amongst theorists of the firm, your freedom to exit a labour relationship at any time makes it the case that all the perceived authority is nothing more than an ongoing consensual affair." As Alchian and Demsetz write, "[firms have] no power of fiat, no

\footnotetext{
${ }^{5}$ I take this example from Anderson (2017: 135), who cites a study from Oxfam America (2016). In the study, multiple workers (using pseudonyms for fear of retribution) cited that it's common to wear diapers and that many workers defecate on themselves while standing in line.

${ }^{6}$ See Anderson (2017: 55).

${ }^{7}$ See Alchian \& Demsetz (1972: 777) as cited in Anderson (2017: 55).
} 
authority, no disciplinary action any different in the slightest degree from ordinary market contracting between any two people" (Alchian \& Demsetz, 1972: 777). ${ }^{8}$ Hence, you might think that since David has the ability to exit at will, nothing but his own volition is holding him back from cancelling the labour contract. Thus, with respect to exit, we might say that David has:

NEGATIVE EXIT: The absence of legal constraints restricting one's possibility of exiting a labour contract at will.

Suppose that David is also actively involved in local politics and feels that he has the actual ability to make his voice heard in elections. Thus, with respect to voice, we might say that David has:

EXTERNAL VOICE: The potential ability to determine the laws governing the relationship between firms and workers.

According to Liberals, such as Berlin (1969), NEGATIVE EXIT and EXTERNAL VOICE are sufficient conditions for political freedom. ${ }^{9}$ To be sure, David might not like some of the laws governing relationships between firms and employees; and he might complain that his preferred political candidates who advocate for more freedom in the workplace are never elected. However, just like everybody else in his state, he gets one vote. In that sense, there is a fair and equal distribution of control on the democratic process. Ultimately, then, if David is still distraught with the conditions of his particular workplace, even after casting his vote, there are no legal constraints restricting his ability to exit and start anew.

\footnotetext{
8 As cited in Anderson (2017: 55).

9 I draw on Hirschman (1970) in carving out the conceptual terrain in the language of "exit" and "voice". I should also note here that, strictly speaking, Berlin (1969) might only claim that NEGATIVE EXIT is sufficient for freedom. However, Pettit (2012: 41) seems to claim that, when speaking of political freedom, Berlin would also hold that something like EXTERNAL VOICE is necessary. However, note that the modal operator here (i.e., potential ability) is restricted to cases where the government would bar you from exercising your voting rights. Thanks to Matthew Palynchuck for pressing me to clarify this.
} 
But is NEGATIVE EXIT and EXTERNAL VOICE sufficient for political freedom? Neo-republicans and relational egalitarians worry that something is missing. ${ }^{10}$ As they see it, the mere possibility to exit a relationship does not rule out that one party is not exercising an arbitrary power over another. For instance, while it is true that David has no legal constraints restricting his ability to exit, it does not follow that David has the actual ability to exit. ${ }^{11}$ Indeed, David's job at the slaughterhouse pays well below what it would cost him to relocate to a new town in hopes of higher pay and better working conditions. Moreover, his erratic work schedule often leaves him too exhausted to consider other options. Hence, David routinely disregards the possibility of leaving the slaughterhouse and starting anew: by his own lights, it is, and probably never will be, a live option. There is both a psychological and financial cost tied to David's exit. Thus, it seems that what David needs is the actual ability to exit, as opposed to the mere possibility to exit:

POSITIVE EXIT: The actual ability to exit a labour contract at will without incurring an unreasonable cost. ${ }^{12}$

So, then, is NEGATIVE EXIT, POSITIVE EXIT, and EXTERNAL VOICE, taken together, sufficient for political freedom? Neo-republicans and relational egalitarians still worry that yet another piece missing. What might be barring David's freedom? According to neo-republicans and relational egalitarians it is

\footnotetext{
${ }^{10}$ See Breen (2015), González-Ricoy (2014; 2020), Hirvonen \& Breen (2020), N. Hsieh (2005), Landes \& Néron (2018), Neron (2015), O’Shea (2019; 2020b), and Vrousalis (2021).

${ }^{11}$ Cf. Levy (2016: 679).

12 The cost here can be either psychological or economic in nature. For instance, suppose that David wants to quit his job in the slaughterhouse to attend college; he knows that, given his financial situation, he will have to incur an unreasonable debt to attend college. And yet, even though a college degree would increase David's earning potential, and give him a more desirable job, it is not clear to him that this choice would be rational. How come? Well, it is important to note that the psychological cost-i.e., the subjective fear of risk-is likely processed in a higher degree for individuals in David's situation since they do not have a robust support system that could bail them out. Similarly, the economic cost-i.e., the actual risk-is likely processed in a higher degree for individuals in David's situation since the debt incurred from education is perceived as worse from David's point of view than it would be from someone who has greater financial resources. To see this, consider David's counterpart_David*_who is like David in all respects, except for one thing: he has a rich uncle who is willing to pay for fifty percent of his education. In this case, it seems like David* has a lower psychological cost insofar as he knows that his rich uncle is cutting the risk in half; and he has a lower economic cost insofar as his rich uncle is artificially altering David*'s set of financial resources. Thus, David* has more POSITIVE EXIT than David.
} 
the fact that David lacks the actual ability to determine the structure of any firm he chooses to work for. To see this, suppose, as we have set it up, that David can actually leave his job at the slaughterhouse and that the cost is relatively low. But suppose further that the only firms that are interested in hiring David are firms that specialize in low-skilled factory work. In addition, due to the nature of David's work, suppose that politicians aren't interested in catering to the interests of David and his co-workers. Every year David goes to the ballot box, but nothing changes. Under such circumstances, you might think that David is still not free from arbitrary interference. ${ }^{13}$ Hence, it seems that David needs the actual ability to participate in the governance of a particular firm:

INTERNAL VOICE: The actual ability to determine how a particular firm, which you are a part of, should be organized. ${ }^{14}$

So, then, is NEGATIVE EXIT, POSITIVE EXIT, EXTERNAL VOICE, and INTERNAL VOICE, taken together, sufficient for political freedom? To put it more precisely, is the following the correct definition of political freedom in the workplace?

WORKPLACE DEMOCRACY: In a certain relationship $R$ between agents $A$ and $B$, where $A$ is a firm and B is an employee, we can say that B is free just in case they have NEGATIVE EXIT, POSITIVE EXIT, EXTERNAL VOICE, and INTERNAL VOICE.

No doubt, there are countless objections to such a definition. Even those in favour of workplace democracy might ascribe to a more moderate characterization of non-domination in the workplace, wherein workers only need the possibility to work at democratic companies. ${ }^{15}$ In addition, it is not

\footnotetext{
13 See Breen (2015) and González-Ricoy (2014) as cited in Jacob \& Neuhäuser (2018: 934).

${ }^{14}$ According to neo-republican and relational egalitarians, non-domination is the absence of non-arbitrary interference. It could be that internal voice is not necessary for non-domination. But for the purposes of this paper, I will assume that it is. For instance, Pettit (2012) might disagree.

15 See Jacob \& Neuhäuser (2018).
} 
clear that all republicans or all neo-republicans would sign on to such a definition. ${ }^{16}$ And finally, we could call into question the neo-republicanism/relational egalitarian grounds that this definition stands on; that is, we might wonder about what is so valuable about the value of equality (as neo-republicans and relational egalitarians construe it). And yet, however pressing these concerns might be, let us bracket them for the moment. For recall that my primary question is not, "Are workers dominated?" For the sake of argument, I take it for granted that they are. My question is: "Does the fact that workers are dominated give us reason to impose restrictions on firms?" This is the question I turn to in the next section.

\section{\3 The Efficiency Objection}

According to the Efficiency Objection there are relevant trade-offs that need to be considered between the efficiency of firms ${ }^{17}$ and the freedom of workers ${ }^{18}$, and upon considering these trade-offs, we should reject workplace democracy. ${ }^{19}$ I follow Dow (2003) in identifying five sorts of justifications for trade-offs that constitute the Efficiency Objection. ${ }^{20}$

1. Democratic workplaces lack controls to ensure that workers don't abuse the assets of a firm. ${ }^{21}$

2. Democratic workplaces lack the ability to monitor employees' performance at work. ${ }^{22}$

\footnotetext{
${ }^{16}$ For instance, internal voice does not seem to be a necessary condition on political freedom according to Pettit (2012).

${ }^{17}$ By "efficiency", I mean the reduction of production costs (i.e., labour, material, supplies, etc.) and transaction costs (i.e., resolving disputes, planning, fees, etc.). For discussion on the relationship between "transaction cost economics" and the efficiency objection see Singer (2018: 832).

${ }^{18}$ Hereafter, when speaking of the trade-off between efficient firms and the freedom of workers, I will understand the "freedom", to pick out the relevant political sense of freedom captured in WORKPLACE DEMOCRACY. Thanks to an anonymous referee for pressing me to clarify this.

${ }^{19}$ See Frega, Herzog, \& Neuhäuser (2019: \$3.1) for an overview.

20 There are potentially more than five sorts of trade-offs that constitute the efficiency objection. Here, I only focus on the five that Dow (2003) has identified. In what follows I will use the term 'democratic workplace' to pick out those workplaces that satisfy the definition of a WORKPLACE DEMOCRACY as I laid out in \$2. I would like to thank an anonymous referee for pressing me to clarify the difference between (i) identifying a trade-off and (ii) identifying a justification for a trade-off.

${ }^{21}$ See Alston \& Gillespie (1989) as cited in Frega et al. (2019: 6).

22 See Alchian \& Demsetz (1972) as cited in Frega et al. (2019: 6).
} 
3. Democratic workplaces cannot incentivize investment from capital owners due to increased risk. ${ }^{23}$

4. Democratic workplaces require workers to concentrate all their capital in the firm that they work at. ${ }^{24}$

5. Democratic workplaces create high additional transaction costs. ${ }^{25}$

Each trade-off, taken individually, might seem to fail to outweigh the freedom of workers; but taken together, each trade-off might tip the scale in favour of enhancing the efficiency of firms. Of course, you might worry that some of these objections are weaker than others. For instance, you might think that (5) does not affect the well-being of workers in the workplace as much as (4); or you might think that workers' freedom is more valuable than the worries that constitute (1) and (2). Or perhaps you might worry that (3) is a serious consideration — so much so that even if all the other trade-offs can be argued away, we still need to address (3). And so on.

Nevertheless, if (1)-(5) all hold, then, taken together, they constitute the strongest version of the Efficiency Objection to workplace democracy. Just as I did not dispute the claim that workers are dominated, so too am I not going to dispute any of the reasons counting in favour of (1)-(5). Rather, for the sake of argument, I'm willing to grant that each objection is prima facie tenable. This is because I am interested in what follows from assuming that (1)-(5) all hold.

As I take it, (1)-(5) pick out both moral and non-moral reasons to reject workplace democracy. It is not important, however, whether any particular reason in (1)-(5) is either a moral or non-moral reason. Some might have different senses. I am not interested in getting tied up in these details. The larger point that I am interested in is that even if there are moral reasons to reject the Efficiency

\footnotetext{
${ }^{23}$ See Dréze (1989) as cited in Frega et al. (2019: 6).

24 See Bonin, Jones, \& Putterman (1993), Dréze (1989), and Gintis \& Bowles (1996) as cited in Frega et al. (2019: 6).

${ }^{25}$ See Hansman (1996) as cited in Frega et al. (2019: 6). See also Singer (2018).
} 
Objection (e.g., workplace domination is an injustice that is not outweighed by pragmatic considerations), we still need to address the non-moral reasons that support it (e.g., if (3) holds then having a reduction in the growth of firms could, in turn, reduce the number of jobs, and as a consequence result in worse outcomes for the worst off amongst us).

The moral case for efficient firms grants that some workers are worse off as a result of relentlessly pursuing efficiency (as we saw with the case of SLAUGHTERHOUSE WORKER). Nevertheless, so the idea goes, efficient firms are better for businesses, shareholders, and consumers. Efficient firms are more profitable, and thus, create more shareholder value. And to create more shareholder value they must compete with other firms, which results in lower prices for products that consumers value. As a result, then, efficient firms produce better overall outcomes for society, and bring benefits to the worst off amongst us.

The non-moral case for efficient firms grants that some workers are dominated, conceding that this is a tragic outcome of modern labour relations. Nevertheless, the non-moral case says that if firms weren't optimally efficient to a degree $x$, then we couldn't have firms. ${ }^{26}(1),(2)$, and (5), taken together, might imply that democratic workplaces can't compete with non-democratic workplaces. Hence, the non-moral reasons outweigh the moral reasons, given that it is not currently feasible to act on the moral reasons. ${ }^{27}$ To sum up, then, we might outline strongest version of the Efficiency Objection as follows:

\footnotetext{
${ }^{26}$ Drawing on Singer (2018) González-Ricoy (2019: \$2.1) writes: “workplace regulation, if fully comprehensive, may cancel the reason why firms exist in the first place."

${ }^{27}$ There might, however, be reasons that concern the second-order feasibility of acting. For instance, you might think that, even if it is not feasible to act on the moral reasons at a time $t_{1}$, it might be feasible to act on non-moral reasons that will make it the case that it is feasible to act on moral reasons at a time $t_{2}$. I leave this issue aside for now. See footnote 33 for further discussion.
} 
EFFICIENCY OBJECTION: (1)-(5), taken together, give us both moral and non-moral reasons to reject workplace democracy.

Let us take stock. To reiterate, the Efficiency Objection does not deny that workers are dominated. Instead, it says that when considering the moral reasons that we have to reduce domination in the workplace, we face a problem; namely, it seems like there are relevant trade-offs_e.g., (1)-(5)—that give us reason enhance the efficiency of firms, even at the expense of increasing workplace domination. These trade-offs, so the Efficiency Objection tells us, constitute both moral and nonmoral reasons to favour non-democratic workplaces. ${ }^{28}$

Before we proceed, I should clarify that the Efficiency Objection only picks out moral and non-moral reasons that fall under the domain of "efficiency." There are other moral and non-moral reasons in the vicinity that I will not discuss (e.g., reasons against imposing paternalistic impositions on firms, and reasons having to do with workers sense of political efficacy, which, in turn, would pose a problem for how such a transition to workplace democracy would be implemented).

Leaving these concerns aside, I will now argue that the Efficiency Objection against workplace democracy fails.

\section{\4 When Efficiency Gives Out}

My argument against the Efficiency Objection goes as follows:

\section{A DILEMMA FOR THE EFFICIENCY OBJECTION}

\footnotetext{
${ }^{28}$ I should note here that the efficiency objection is not an all-things-considered objection to workplace democracy-there may be other considerations which count in favour of rejecting workplace democracy (see $\$ 5$ ). Proponents of the efficiency objection might agree that some moral reasons tip the scale against efficiency concerns. What these moral reasons are, however, is what is under dispute. Thus, proponents of the efficiency objection might claim that the moral reason which justifies inequalities in distribution is efficiency — the implicit morality of the market C.f. McMahon (2012: 126-127) and Heath (2007: 369). Thanks to an anonymous referee for asking me to clarify this.
} 
(P1) Either the efficiency objection is justified on moral grounds or non-moral grounds.

(P2) If the efficiency objection is justified on non-moral grounds, then it fails.

(P3) If the efficiency objection is justified on moral grounds, then it fails

(C) Therefore, the efficiency objection fails.

The first premise of my argument is a trivial truth. Let us turn to the second premise of my argument. The non-moral reasons concern the overall feasibility of WORKPLACE DEMOCRACY. The idea is that firms need to sustain an optimal level of efficiency in order to continue to exist. The third reason that features in the efficiency objection best encapsulates this:

(3) Democratic workplaces cannot incentivize investment from capital owners due to increased risk. ${ }^{29}$

This does present a substantial challenge to the feasibility of democratic workplaces in a world of nondemocratic workplaces. Even a cursory glance at the flows of global capital will reveal that higher rates of investment are seen in areas of the world where labour laws are less restrictive. And yet, while this may be true, it is important to point out that the non-moral reasons do not always outweigh the moral reasons. Suppose we thought otherwise. We would always have to cede our moral interests to the interests of business; we would have to put aside our concerns of justice and workers' rights whenever we encounter the prospect of a decrease in efficiency. But it is evident that we do not do this. Why is this so? It is because we recognize that firms do not exist for their own sake-they are not good in

\footnotetext{
${ }^{29}$ See Dréze (1989) as cited in Frega et al. (2019: 6).
} 
themselves. They are, rather, instrumentally good, which is why it makes sense to ask: What is the point of efficient firms?

The answer to this question cannot be that we value efficiency for its own sake; for efficiency is always directed towards producing more of something or producing something at a cheaper rate (i.e., lowering transaction costs). It makes no sense to value efficient firms for their own sake. However, it does make sense to value efficient firms for what they bring about. Yet, notice that all the cited reasons to value efficient firms are reasons that count in favour of bringing about valuable moral goods; that is, they are said to bring about more goods and services that would enhance aggregate well-being. Hence, the non-moral reasons that we have to value efficient firms are only instrumental reasons, which get their relative weight from their being directed at some other moral good. But if this is so, then the non-moral reasons that count against trading off efficient firms for workers' freedom are only valuable insofar as they realise some other moral good. ${ }^{30}$ So even if it is at present, unfeasible, we cannot infer that we should not care about making it feasible in some future state of affairs. Rather, if the moral reasons always outweigh the non-moral reasons, then that is precisely what we should do.

This raises an important question: what does it mean to act on reasons that concern the second-order feasibility of action? $?^{31}$ To answer this question, let us consider another case:

\footnotetext{
${ }^{30}$ For example, with (3) the worry seems to be that, since democratic workplaces can't compete with non-democratic workplaces, countries that employ the former types of regulations on firms will not be able to compete with foreign investment, and, as a consequence, there will be fewer firms, which results in less opportunities for the least well off amongst us. Although (3) is a non-moral reason concerned with the overall feasibility, the worry that underlies it is moral in nature: there will be less opportunities for the least well off amongst us.

${ }^{31}$ I owe my phrasing of this to Pablo Gilabert. By "second-order feasibility", I mean the feasibility of some action in a future context. For instance, it's feasible that I wake up and run 5 miles tomorrow. But it's not feasible that I wake up and run a marathon tomorrow. If I have a reason to run a marathon then I ought to perform those actions that make it the case that it will be feasible for me to run a marathon. Thus, I have reason to run 6 miles tomorrow, 7 the day after, 8 the next week, and so on. Here, I discuss second-order feasibility because when discussing first-order feasibility, the nonmoral reasons can outweigh the moral reasons (e.g., the fact that democratic workplaces can't compete with nondemocratic workplaces due to their inability to attract capital investment). To take a step back, then, and discuss secondorder feasibility is ask what we would do if it were the case that the non-moral reasons that we have to value efficient firms did not hold. Thanks to an anonymous referee for pushing me to clarify this.
} 
Slaughterhouse Manager: Thomas is the manager of a slaughterhouse in California. Temperatures in the slaughterhouse often reach a sweltering 100 degrees Fahrenheit, and due to a lack of adequate bathroom breaks, Thomas' employees are forced to either wear diapers or defecate on themselves. ${ }^{32}$ Moreover, despite the obvious exhaustion of the employees, Thomas continues to pressure workers to ever-increasing productivity; he is in middle-management and he has constant pressure from the CEO to increase productivity. Day in and day out, Thomas contemplates doing something to alter the awful working conditions. But the CEO often threatens to fire managers who do not meet the strictly enforced productivity targets, which rise year after year. Finally, Thomas has no power to make any substantial changes to the workplace-that is for the CEO and the board of directors to decide. He works long hours and is often too exhausted to do anything but recover on his days off. Hence, Thomas routinely disregards his nagging desire to do something to help the workers at the slaughterhouse.

Just like in the case of SLAUGHTERHOUSE WORKER, we see that in SLAUGHTERHOUSE MANAGER, Thomas has no ability to alter the structure of the firm that he works at. Thomas lacks, as David does, INTERNAL VOICE. So, then, what is Thomas to do? Is he in the same position as David, with the only difference being that he is a few ranks higher?

In some sense, he is. For even if David and Thomas have good moral reasons to change the way things are, it is not feasible for them to act on those moral reasons at present. However, even if it is not feasible to act on the moral reasons at a time $t_{1}$, it might be feasible to act on further reasons that will make it the case that it is feasible to act on moral reasons at a time $t_{2}$. For instance, both David and Thomas might engage in political activities that undermine the abilities of firms to compete using

\footnotetext{
32 Again, see Anderson (2017: 135).
} 
unjust means. For example, they might vote for political candidates that place constraints on unjust labour practices, which would restrict the options that firms have to compete via exploitation. Suppose that this is feasible for David and Thomas. If that is so, then both David and Thomas are contributing to the second-order feasibility of the moral reasons outweighing the non-moral reasons. They can both recognize that, even if it is not feasible to act on the moral reasons at a time $t_{1}$, it is feasible to act on further reasons that will make it the case that it is feasible to act on moral reasons at a time $t_{2}$. In this way, then, the non-moral reasons that we might have to value efficient firms in the short-term are not outweighed by the moral reasons that we have to value human freedom in the long-term.

I conclude that if we try to justify the efficiency objection on non-moral grounds, we must find some reason to value efficiency for its own sake; but there are only non-moral reasons to value efficiency (it is only instrumentally good). And since the moral reasons outweigh the non-moral reasons, there is no way to justify trading off workers' freedoms for efficient firms on non-moral grounds. Hence, if the efficiency objection is justified on non-moral grounds, then it fails; for the other side of the scale clearly outweighs the harms that flow from slightly less efficient firms.

Let us now turn to my third premise. For the sake of argument, I will grant that efficient firms produce better overall consequences for society and bring benefits to the worst off amongst us. However, I think that it is important to establish that at least some reasons can count in favour of upholding individual human freedom, even if doing so results in less efficient firms. To see this, consider the following case:

1\% CHILD LABOUR: Imagine a society in which $1 \%$ of all children are forced against their will to work at a factory making toys. Temperatures in the toy factory often reach a sweltering 100 degrees Fahrenheit, and due to a lack of adequate bathroom breaks, some of the children develop serious health issues. Moreover, despite the obvious exhaustion of 
the children, they are not permitted to leave the factory until they are 18 years of age. However, the children play a crucial role in this society: had the children not been forced to work against their will, those firms engaged in making toys would be highly inefficient, and, as a result, there would be less toys for the other children. Nevertheless, given the labour relations in this society, it turns out that there is an abundance of toys, and as a consequence, the aggregate well-being of the $99 \%$ of the children is much higher.

Let us grant that the $99 \%$ of children are happy as a result of having an abundance of toys; and let us also grant that the suffering of the $1 \%$ of children only creates a net loss of $1 \%$ in aggregate wellbeing. Nevertheless, it still seems like we do not have reason to allow such a practice to continue in society. Although 1\% CHILD LABOUR is highly efficient, it is not a just way to organize labour relations; for the benefits that flow from unrestricted use and abuse of children's labour is outweighed by the reasons that we have the respect their rights. Thus, it seems that at least some reasons can count in favour of upholding individual human freedom in the workplace-even if doing so results in a net loss of aggregate well-being. Put somewhat more abstractly, what $1 \%$ CHILD LABOUR shows us is that we would prefer the world where there are at least some deontic constraints on what can be tradedoff for more efficient firms. Of course, the bar with $1 \%$ CHILD LABOUR is set quite low since the children lack NEGATIVE EXIT. Setting the bar higher, proponents of WORKPLACE DEMOCRACY aim to show that the scope of these deontic constraints also includes POSITIVE EXIT, EXTERNAL VOICE, and INTERNAL VOICE. To get a rough sense ${ }^{33}$ of this, consider the table below:

\footnotetext{
${ }^{33}$ Note that the table might not capture some of the fine-grained distinctions between these views (e.g., the relative scope, nature, grounds, and instantiated form of INTERNAL VOICE). By "Liberals" I have in mind Berlin (1969) and other nearby views; and by "Republican" I have in mind views like Pettit (2012) and Jacob \& Neuhäuser (2018), which are sympathetic with Republican ideals, yet reject INTERNAL VOICE; and by "Neo-republican" and "Relational Egalitarian", I have in mind the more robust views that accept something like INTERNAL VOICE, i.e., Hseih (2005), Gourevitch, (2013), Landemore \& Ferreras (2016, Anderson (2017), González-Ricoy (2014); (2019); (2020), O’Shea (2019); (2020a); (2020b). Thanks to an anonymous referee for suggesting me to clarify this, which prompted a minor change to the table.
} 
THE SCOPE OF DEONTIC CONSTRAINTS

\begin{tabular}{|l|l|l|l|l|}
\hline & $\begin{array}{l}\text { Are there } \\
\text { deontic } \\
\text { constraints on } \\
\text { trading-off } \\
\text { NEGATIVE EXIT } \\
\text { for efficiency? }\end{array}$ & $\begin{array}{l}\text { Are there deontic } \\
\text { constraints on } \\
\text { trading-off } \\
\text { POSITIVE EXIT } \\
\text { for efficiency? }\end{array}$ & $\begin{array}{l}\text { Are there deontic } \\
\text { constraints on } \\
\text { trading-off } \\
\text { EXTERNAL VOICE } \\
\text { for efficiency? }\end{array}$ & $\begin{array}{l}\text { Are there deontic } \\
\text { constraints on } \\
\text { trading-off } \\
\text { INTERNAL VOICE } \\
\text { for efficiency? }\end{array}$ \\
\hline Liberals & $\sqrt{ }$ & & $\sqrt{ }$ & \\
\hline Republicans & $\sqrt{ }$ & $\sqrt{ }$ & $\sqrt{ }$ & $\sqrt{ }$ \\
\hline $\begin{array}{l}\text { Neo-Republicans } \\
\text { and Relational } \\
\text { Egalitarians }\end{array}$ & $\sqrt{ }$ & $\sqrt{ }$ & $\sqrt{ }$ & \\
\hline
\end{tabular}

Now let us turn back to the case of Slaughterhouse WORKER. Where Neo-republicans and relational egalitarians part ways from Republicans and Liberals is that they hold that there is a duty to supply David with INTERNAL VOICE; moreover, they hold that this duty is a deontic constraint on the possible gains to be had from more efficient firms. Now, here's the interesting question: is the deontic constraint of INTERNAL VOICE overridable? My answer to this question is a qualified "yes." More precisely, I hold that we can tip the scales in favour of efficiency to warrant a higher degree of domination in the workplace-but there is a threshold: some cases of workplace domination are so severe that no gains in efficiency could ever override them. Determining the threshold supplies us with an account of the relative scope of INTERNAL VOICE. The proper scope of internal voice on my account thus rules out that workers have the right to determine any organizational aspect of a firm; rather, I hold that workers have a right to determine only those aspects of a firm that contribute to severe workplace domination. ${ }^{34}$ So, then, what constitutes severe workplace domination?

\footnotetext{
34 This is because, on my view, workers might find it desirable to consent to domination in the workplace if it results in a greater monetary or non-monetary benefit. This might be a trade-off worth making.
} 
To answer this question, consider some of the issues that workers in the bottom half of American society face in their respective firms: the lack of bathroom breaks; the sexual harassment; the fear of reporting an injury; the abusive managers; the fraud, rape, beatings, torture, psychological manipulating, intimidation, and exhausting hours; and to top it off, all of these abuses occur in industries collectively employing over "tens of millions of workers" (Anderson, 2017: 135-37).

I take it that all of these aforementioned concerns give us at least some reason to uphold individual human freedom in the workplace, even if doing so results in lower efficiency, which gives rise to a net loss of aggregate well-being (e.g., prices are higher on goods and services that those in the bottom half of society consume more of). Even if we are speaking of aggregate well-being, it is not clear that the bottom half of the labour force would rationally choose to have no say in how they are governed at work (with respect to these severe cases) just because they are concerned higher efficiency, which, in turn, creates marginally cheaper goods and services. However, if we are speaking of the wellbeing of the owners and shareholders of firms, it does seem like an instrumentally rational choice to pick higher efficiency over the well-being of workers; such a choice increases competitive advantage, and consequently, benefits the owners and shareholders of firms.

At this point, proponents of non-democratic workplaces might cite that, in the long-term, the gains from efficiency reduce domination in the workplace more than the regulation that proposes to give workers INTERNAL VOICE. ${ }^{35}$ And so, we are again faced with a trade-off. On the one hand, it is a plausible empirical assumption that if we tolerate some domination in the workplace in the near-term, it will naturally decrease vis-à-vis technological innovation in the long-term. And on the other hand, we might find some lower-bound of domination in the workplace so objectionable that even if it results in lower workplace domination in the long-term (via job growth or technological innovation)

\footnotetext{
35 An anonymous referee points out that common arguments for non-democratic workplaces cite that the gains from efficiency are indirectly beneficial to workers due to resultant growth and technological innovation. For discussion on this see Von Mises (1935) and Roemer (1994).
} 
we might still deem it morally objectionable. ${ }^{36}$ And yet, in this case, it seems like we have reasons of justice to respect workers' rights even if tolerating workplace domination in the long-term would actually serve their collective interests. Indeed, it seems perverse, as Anderson (2017: 138) suggests, to tie the amount of (basic) respect, standing, and autonomy a person gets to their market value. Treating a person as a person requires that we don't tie (i) their market value to (ii) living a dignified life in the workplace. To think otherwise, is to treat a person as a mere thing, which has a price. ${ }^{37}$

I conclude that if we try to justify the efficiency objection on moral grounds, the goods that efficient firms produce are unequally distributed to the owners and shareholders of firms; and if they are unequally distributed, then there must be some moral reason that justifies such an inequality. But there is no moral reason to justify such an inequality because the efficiency gains do not outweigh our duty to respect the autonomy of workers. Thus, it seems that if the efficiency objection is justified on moral grounds, then it fails; for the other side of the scale clearly outweighs the harms that flow from slightly less efficient firms.

I conclude that the efficiency objection fails.

\section{$\$ 5$ Conclusion}

Let us take stock. In $\int \S 1-2$, I briefly outlined the relational egalitarian and neo-republican case that workers are dominated. I then posed a question: does the fact that workers are dominated give us reason to impose restrictions on firms? In $\$ 3, \mathrm{I}$ introduced the Efficiency Objection, and outlined how it is either justified on moral or non-moral grounds. In $₫ 4$, I argued that both the moral and non-moral justifications for the efficiency objection fail. The non-moral case fails because it mistakenly ascribes efficiency as a good in itself. But efficiency is only instrumentally good for what it brings about. Thus,

\footnotetext{
${ }^{36}$ For instance, many find it wrong to leave unjust workplace discrimination to the market to sort out.

${ }^{37}$ See Kant (2010: 42) at 4:435. For an illuminating discussion on the Kantian person/thing principle see Ellerman (1988: 1111) and Cohen (2003: 706).
} 
even if there are non-moral reasons for acting in favour of efficiency at a time $t_{1}$, there are further reasons to act on that will make it the case that it is feasible to act on moral reasons at a time $t_{2}$. And, in this case, we have reason to pursue workers' freedom over the efficiency of firms. The moral case fails because severe workplace domination is not subject to trade-offs between efficiency and freedom. To think otherwise is to violate a deontic constraint on workers' freedom, namely, that they be treated as persons and not mere things. Thus, the efficiency objection fails.

It is important to note that there are still other objections to be made against WORKPLACE DEMOCRACY. There is still what Frega, Herzog, \& Neuhäuser (2019) identify as the feasibility objection (which says that such a transition might be unrealistic) and the arguments from liberalism (which say that it is unjust to restrict the freedom of employees to work for hierarchical firms). I have not addressed these objections in this paper. I have only made the claim that the Efficiency Objection against workplace democracy fails. I hope to have shown that the reasons we have to value efficient firms are not outweighed by the reasons that we have to value human freedom in the workplace. ${ }^{38}$

\footnotetext{
${ }^{38} \mathrm{I}$ wish to thank the editor and two anonymous referees for their extremely valuable feedback and extensive comments on this paper. I also owe a special thanks to Robbie Dillon, Ian Gold, Morgan Gagnon, Chris Howard, Mylene Hangdaan, Sierra James, Stephanie Leary, Matthew Palynchuck, Eric Séguin, Natalie Stoljar, and for their helpful comments. And lastly, thanks to Pablo Gilabert for allowing me to audit his fantastic graduate seminar on Domination (Winter 2020).
} 


\section{REFERENCES}

Alchian, A. A., \& Demsetz, H. (1972). Production, Information Costs, and Economic Organization. The American Economic Review, 62(5), 777-795.

Alston, L. J., \& Gillespie, W. (1989). Resource Coordination and Transaction Costs: A Framework for Analyzing the Firm/Market Boundary. Journal of Economic Behavior and Organization, 11, 191212.

Anderson, E. (2015). Equality and freedom in the workplace: Recovering republican insights. Social Philosophy and Policy, 31(2), 48-69.

Anderson, E. (2017). Private Government: How Employers Rule Our Lives (and Why We Don't Talk about It). New Jersey: Princeton University Press.

Berlin, I. (1969). Four Essays on Liberty. Oxford: Oxford University Press.

Bonin, J. P., Jones, D. C., \& Putterman, L. (1993). Theoretical and Empirical Studies of Producer Cooperatives: Will Ever the Twain Meet? Journal of Economic Literature, 31(3), 1290-1320.

Breen, K. (2015). Freedom, republicanism, and workplace democracy. Critical Review of International Social and Political Philosophy, 18(4), 470-485.

Breen, K. (2017). Non-domination, workplace republicanism, and the justification of worker voice and control. International Journal of Comparative Labour Law and Industrial Relations, 33(3), 419-439.

Cohen, G. (2003). The price of everything, the value of nothing: Reframing the commodification debate. Harvard Law Review, 117(2), 689-710.

Dow, G. (2003). Governing the Firm: Workers Control in Theory and Practice. Cambridge: Cambridge University Press.

Dréze, J. (1989). Labour management, contracts, and capital markets: a general equilibrium approach. Oxford: Blackwell. 
Ellerman, D. (1988). The Kantian Person/Thing Principle in Political Economy. Journal of Economic Issues, 22(4), 1109-1122.

Frega, R., Herzog, L., \& Neuhäuser, C. (2019). Workplace democracy-The recent debate. Philosopby Compass, 14(4), 1-11.

Frye, H. (2020). Efficiency and Domination in the Socialist Republic: A Reply to O'Shea. Political Theory, 48(5), 573-580.

Gintis, H., \& Bowles, S. (1996). The Distribution of Wealth and the Viability of the Democratic Firm. In U. Pagano \& R. R (Eds.), Democracy and Efficiency in the Economic Enterprise (pp. 82-97). New York: Routledge.

Gonzalez-Ricoy, I. (2020). Ownership and control rights in democratic firms-a republican approach. Review of Social Economy, 78(3), 411-430.

González-Ricoy, I. (2014). The Republican Case for Workplace Democracy. Social Theory and Practice, 40(2), 232-254.

González-Ricoy, I. (2019). Firm Authority and Workplace Democracy: a Reply to Jacob and Neuhäuser. Ethical Theory and Moral Practice, 22(3), 679-684.

Gourevitch, A. (2013). Labor Republicanism and the Transformation of Work. Political Theory, 41(4), $591-617$.

Hansman, H. (1996). The Ownership of Enterprise. Cambridge, MA: Harvard University Press.

Heath, J. (2007). An adversarial ethic for business: Or when Sun-Tzu met the stakeholder. Journal of Business Ethics, 72(4), 359-374.

Hirschman, A. O. (1970). Exit, voice, and loyalty: responses to decline in firms, organizations, and states. Cambridge, MA: Harvard University Press.

Hirvonen, O., \& Breen, K. (2020). Recognitive arguments for workplace democracy. Constellations, 27(4), 716-731. 
Hsieh, N. (2005). Rawlsian Justice and Workplace Republicanism. Social Theory and Practice, 31(1), $115-142$.

Jacob, D., \& Neuhäuser, C. (2018). Workplace Democracy, Market Competition and Republican Self-Respect. Ethical Theory and Moral Practice, 21(4), 927-944.

Kant, I. (2010). Groundwork of the Metaphysics of Morals. (M. Gregor, Ed.) (16th ed.). New York: Cambridge University Press.

Landemore, H., \& Ferreras, I. (2016). In defense of workplace democracy: Towards a justification of the firm-state analogy. Political Theory, 44(1), 53-81.

Landes, X., \& Néron, P. Y. (2018). Morality and market failures: Asymmetry of information. Journal of Social Philosophy, 49(4), 564-588.

Levy, J. T. (2016). Coherence, Consistency, Equality: On Pettit’s Republican Democracy. Political Theory, 44(5), 679-686.

McMahon, C. (2012). Public capitalism: The political authority of corporate executives. Philadelphia, PA: University of Pennsylvania Pres.

Von Mises, L. (1935). Economic Calculation in the Socialist Commonwealth. In F. A. Hayek (Ed.), Collectivist economic planning. (2nd ed., pp. 87-130). London: Routledge \& Kegan Paul.

Neron, P. Y. (2015). Rethinking the Very Idea of Egalitarian Markets and Corporations: Why Relationships Might Matter More than Distribution. Business Ethics Quarterly, 25(1), 93-124.

Néron, P. Y. (2015). Social equality and economic institutions: Arguing for workplace democracy. In G. Hull (Ed.), The equal society (pp. 311-331). Lanham, MD: Lexington Books.

O’Neill, M. (2017). Survey Article: Philosophy and Public Policy after Piketty. Journal of Political Philosophy, 25(3), 343-375.

O’Shea, T. (2019). Are Workers Dominated? Journal of Ethics and Social Philosophy, 16(1), 1-24.

O’Shea, T. (2020a). Socialist Republicanism. Political Theory, 48(5), 548-572. 
O’Shea, T. (2020b). In Defence of Public Ownership: A Reply to Frye. Political Theory, 48(5), 581587.

Oxfam America. (2016). No relief: Denial of bathroom breaks in the poultry industry, 1-13.

Pettit, P. (2012). On The People's Terms. Cambridge: Cambridge University Press.

Roemer, J. (1994). A future for socialism. Cambridge, MA: Harvard University Press.

Singer, A. (2018). The political nature of the firm and the cost of norms. Journal of Politics, 80(3), 831844.

Vrousalis, N. (2021). The Capitalist Cage: Structural Domination and Collective Agency in the Market. Journal of Applied Philosophy. 38(1), 40-54. 